\title{
Model Lewin Dalam Manajemen Perubahan: Teori Klasik Menghadapi Disrupsi Dalam Lingkungan Bisnis
}

\author{
Dina Mellita \\ Universitas Bina Darma \\ Email: dinamellita@binadarma.ac.id \\ Efan Elpanso \\ Universitas Bina Darma \\ Email: efan.elpanso@binadarma.ac.id
}

\begin{abstract}
At present the business environment is entering its third decade in the 21 st century. Business today is more modern and dynamic and is colored by various disruption. Disruption in this case is disruption of technology, politics, economy and social culture. In the management of organizational change, Lewin's Model is known as a classical theory and as a guide for organizations to implement, manage and evaluate change. This study aims to identify whether Lewin's model which is considered a classic is still adaptive for use in a business environment that is recruited. By using conceptual research methods it is known that the three stages of Lewin put forward the individual or human as the root of change through the identification of the driving factors and drivers of change. In this model, the leadership style is more oriented to involvement, commitment and support and orientation to sharing knowledge for the success of the change process in the organization. With these factors in Lewin's stage, changes as a result of disruption in the business environment in the organization will be effective. Keywords: Change Process, Refreezing, Leadership Style
\end{abstract}

\begin{abstract}
Abstrak
Pada saat ini lingkungan bisnis memasuki dasawarsa ketiga dalam abad 21. Bisnis pada saat ini lebih modern dan dinamis dan diwarnai oleh berbagai disrupsi. Disrupsi dalam hal ini adalah disrupsi teknologi, politik, ekonomi dan sosial budaya. Dalam manajemen perubahan organisasi, Model Lewin dikenal sebagai teori klasik dan sebagai pedoman bagi organisasi untuk mengimplementasikan, mengelola dan mengevaluasi perubahan. Penelitian ini bertujuan untuk mengidentifikasi apakah Model Lewin yang dianggap klasik tersebut masih adaptif untuk digunakan dalam lingkungan bisnis yang disrutif. Dengan menggunakan metode penelitian konseptual diketahui bahwa tiga tahapan Lewin mengedepankan individu atau manusia sebagai akar dari perubahan melalui identifikasi faktor pendorong dan penggerak perubahan. Dalam model ini juga mengedepankan gaya kepemimpinan lebih berorientasi pada keterlibatan, komitmen dan dukungan serta orientasi berbagi pengetahuan untuk keberhasilan proses perubahan dalam organisasi. Dengan faktor-faktor tersebut dalam tahapan Lewin, perubahan sebagai akibat dari adanya disrupsi pada lingkungan bisnis pada organisasi akan berjalan efektif.
\end{abstract}

Kata kunci: Proses Perubahan, Refreezing, Gaya Kepemimpinan

\section{Pendahuluan}

Bisnis merupakan suatu konsep yang dipahami sebagai usaha dari suatu organisasi atau perusahaan untuk menyediakan barang dan jasa bagi konsumen. Ukuran suatu bisnis dapat dilihat dari jumlah pegawai ataupun volume penjualan. Namun diatas semua itu, semua bisnis memiliki tujuan utama yang sama yaitu untuk mendapatkan keuntungan atau profit. Selain itu, keberadaan bisnis juga dimaksudkan sebagai institusi penting dalam masyarakat, penyediaan barang dan jasa, menciptakan lapangan pekerjaan, menawarkan kualitas hidup yang lebih baik, berkontribusi pada pertumbuhan ekonomi negara. Dengan demikian, dapat diambil kesimpulan bahwa bisnis memiliki peran krusial dalam kehidupan masyarakat. Dalam hal ini masyarakat dan bisnis tidak dapat dipisahkan antara satu dan lainnya.

Pada saat ini lingkungan bisnis memasuki dasawarsa ketiga dalam abad 21. Bisnis pada saat ini lebih modern dan dinamis. Perkembangan transformasi digital dan kepedulian terhadap masalah lingkungan menjadi pemicu bagi banyak organisasi perusahaan untuk menggali 
potensi yang dimiliki (Mellita dkk, 2020). Pada masa ini, organisasi yang besar dengan jumlah tenaga kerja yang banyak tidak akan eksis lagi. Kondisi bisnis pada saat ini lebih berorientasi pada pengetahuan (knowledge-based) dan teknologi informasi menguasai semua pekerjaan. Otoritas linier dalam hal ini akan semakin berkurang dan ketaatan kepada atasan juga akan semakin hilang. Pada saat ini juga renumerasi akan tergantung pada kontribusi individu pada organisasi.

Lingkungan bisnis saat ini menghadapi disrupsi sebagai akibat dari perkembangan teknologi. Disrupsi membawa aktivitas lingkungan bisnis saat ini menjadi dinamis. Hal ini diibaratkan pisau bermata dua, yaitu sebagai ancaman atau menawarkan peluang yang luar biasa bagi suatu bisnis. Lingkungan bisnis didalamnya meliputi faktor-faktor sosial-ekonomi, teknologi, pemasok, pesaing dan pemerintah. Selain itu terdapat dua faktor lagi yang akan mempengaruhi bisnis, yaitu lingkungan fisik atau alam dan lingkungan global.

Disrupsi dalam lingkungan bisnis modern pada abad ini juga lebih merujuk pada perubahan. Secara harfiah perubahan telah menjadi bagian dari kehidupan individu dan perusahaan. Dalam hal ini sebagian besar organisasi menghadapi urgensi perubahan dalam operasional mereka sehari-hari. Semakin dinamisnya lingkungan bisnis saat ini mendorong perubahan pada tingkat yang belum pernah terjadi sebelumnya. Untuk menghadapinya diperlukan perubahan manajemen secara terencana. Perubahan manajemen yang terencana membantu baik individu, masyarakat, organisasi dan komunitas untuk memecahkan masalah, belajar dari pengalaman yang telah lalu dan yang akan datang, beradaptasi dengan lingkungan dan perubahan, mengganti persepsi yang sudah ada, meningkatkan kinerja serta mempengaruhi perubahan di masa yang akan datang (Calder, 2013).

Salah satu teori klasik yang dalam mengelola perubahan adalah Teori Kurt Lewin yang dikenal dengan istilah Model Lewin. Model ini mendeskripsikan tahapan-tahapan dalam melakukan perubahan terencana dan perbaikan secara terus menerus membantu dalam keberlanjutan jangka panjang dalam suatu manajemen organisasi. Perubahan terencana diklasifikan sebagai saha yang disengaja dilakukan dengan perhitungan yang matang sertabersifat kolaboratif untuk menghasilkan perbaikan dalam system dengan bantuan agen perubahan (Roussel, 2006). Dapat dikatakan bahwa perubahan terencana merupakan proses yang kompleks.

Teori Lewin dikenal secara eksplisit menegaskan bahwa perubahan merupakan hal yang nyata. Sangat penting bagi manajer ataupun agen perubahan untuk mengidentifikasi teori atau model perubahan yang sesuai yang menyediakan kerangka kerja dapat mengimplementasikan, mengelola dan mengevaluasi perubahan (Wren, J., dan Dulewicz, V, 2005). Setiap teori memiliki cara tersendiri dalam menguji perubahan dan menguraikan bagaimana perubahan tersebut terjadi. Adanya disrupsi yang mendorong organisasi untuk melakukan perubahan. Yang jadi pertanyaan adalah apakah teori klasik Lewin masih bisa digunakan dalam lingkungan bisnis yang terdisrupsi?

Penelitian ini bertujuan untuk menguraikan Teori Lewin sebagai teori klasik dari manajemen perubahan yang dapat digunakan dalam menghadapi disrupsi dalam dunia bisnis modern. Dalam kajian ini akan diuraikan konsep dasar dari Teori Lewin, disrupsi dalam konsep manajemen, tahapan-tahapan Lewin dalam perubahan yang direncanakan serta kativitas- 
aktivitas yang dilakukan dalam setiap tahapannya serta argument-argumen mengenai kekuatan teori klasik ini menghadapi dinamika lingkungan bisnis yang disruptif.

\section{Literature Review}

2.1 Disrupsi Dalam konsep Manajemen

Disrupsi atau gangguan adalah kejadian yang mengganggu acara, proses, sistem atau paradigma. Disrupsi lebih kepada adanya kekuatan yang datang melanggar aktivitas, system atau proses yang normal sedang berjalan. Akar dari disrupsi dalam konsep manajemen didiskusikan dalam kajian Christensen mengenai inovasi (Christensen, 1997). Dalam kajiannya, Christensen memperkenalkan konsep inovasi disruptif (disruption innovation) atau suatu proses antisipasi yang cepat merupakan kebutuhan di masa yang akan datang dan perkembangan yang cepat dari barang, jasa dan proses. Secara spesifik, Christensen memisahkan teknologi baru menjadi teknologi yang berkelanjutan dan disrupsi. Teknologi berkelanjutan merupakan perkembangan teknologi yang dimaksudkan untuk meningkatkan keberlanjutan dari teknologi yang sudah ada. Di sisi lain, teknologi disruptif merefleksikan antisipasi dari paramaeter-parameter terbentuk. Antisipasi dan penyesuaian tersebut akan mengguncang pasar dan selanjutnya dominasi-dominasi yang terjadi di pasar tergantikan oleh innovator kecil yang lebih gesit.

Kajian yang dilakukan oleh McKinsey mengemukakan tiga sumber utama terjadinya disrupsi, yaitu adanya pergerakan lokus ekonomi, perubahan teknologi yang cepat dan adanya revolusi informasi (Dobbs et al., 2004). Melalui kajiannya juga McKinsey mendapati bahwa ketiga sumber disrupsi tersebut secara natural mendorong adanya gangguan di bidang politik dan sosial budaya.

\subsection{Tiga Tahap Teori Lewin dalam Manajemen Perubahan}

Kurt Lewin memperkenalkan model perubahan terencana dalam 3 tahapan, yaitu Mencairkan (Unfreeze), Perubahan (Movement) dan Membekukan Kembali (Refreeze). Menurut Lewin, langkah pertama dalam proses perubahan perilaku adalah mencairkan situasi atau status quo yang ada. Status quo disini dianggap sebagai keadaan keseimbangan yang berlaku. Proses mencairkan merupakan proses yang diperlukan untuk mengatasi tekanan secara individual dan kelompok serta dilakukan melalui 3 metode, pertama dengan meningkatkan faktor-faktor pengerak yang bisa menjauhkan individu atau kelompok dari situasi status quo yang berlaku saat ini.

Kedua, mengurangi kekuatan-kekuatan negatif yang dapat menahan pergerakan yang menjauhi kondisi keseimbangan saat ini. Sedangkan metode ketiga adalah menemukan kombinasi dari dua metode diatas. Dalam kondisi ini ini, terdapat beberapa aktivitas yang dapat membantu proses mencairkan, termasuk didalamnya adalah memotivasi peserta perubahan dengan menyiapkan mereka untuk perubahan, membangun kepercayaan dan mengenali kebutuhan akan perubahan serta secara aktif berpartisipasi dalam mengidentifikasi permasalahan dan berdiskusi secara berkelompok untuk menemukan solusinya (Robbins, 2003).

Tahapan kedua dalam model Lewin adalah perubahan (Movement). Dalam tahap ini, merupakan hal yang penting untuk menggerakkan system yang ditargetkan menuju keseimbangan baru. Terdapat tiga aktivitas yang dapat membantu dalam proses pergerakan ini, yaitu meyakinkan karyawan atau peserta bahwa kondisi status quo yang mereka jalani 
saat ini tidak bermanfaat dan memotivasi mereka untuk melihat permasalahan dari sudut pandang yang baru dan berbeda, bekerja secara bersama-sama dalam hal-hal yang baru, memiliki informasi yang relevan serta memiliki hubungan antara yang satu dengan yang lainnya dengan saling menghormati serta memiliki pimpinan yang mendukung perubahan tersebut.

Tahap ketiga dari model Lewin adalah membekukan kembali (Refreezing). Tahap ini perlu dilakukan setelah perubahan diimplementasikandengan tujuan untuk mempertahankan keberlanjutannya. Jika tahap ini tidak dilakukan, perubahan yang terjadi akan berlaku secara singkat dan prilaku akan kembali ke kesimbangan yang lama. Tahapan ini merupakan proses integrasi dari nilai-nilai yang baru untuk berlaku pada komunitas yang ada. Tujuan utama dari tahap ini adalah untuk stabilisasi keseimbangan baru yang dihasilkan dari perubahan dengan menyeimbangkan antara faktor-faktor penggerak dan penghambat perubahan. Salah satu tindakan yang dapat digunakan untuk mengimplementasikan langkah ketiga dari Lewin ini adalah memperkuat pola baru dan menetapkan pola-pola tersebut dalam bentuk mekanisme secara formal dan informal termasuk didalamnya meliputi kebijakan dan prosedur (Robbins, 2005).

Dapat disimpulkan bahwa Model Lewin mengilustrasikan pengaruh kekuatan baik yang mendorong atau menghambat perubahan. Dalam hal ini, faktor penggerak yang akan mendorong perubahan secara positif, sedangkan faktor penghambat akan menahan perubahan kembali kepada status uo yang berlaku sebelumnya. Dengan demikian, perubahan akan terjadi ketika faktor penggerak lebih besar dibandingkan faktor penghambat.

\section{Metode Penelitian}

Penelitian ini menggunakan metode penelitian konseptual (conceptual research methods). Penelitian konseptual didefinisikan sebagai metodologi di mana penelitian dilakukan dengan mengamati dan menganalisis informasi yang sudah ada pada topik yang diberikan (Camp, 2001). Secara spesifik dalam penelitian ini akan diuraikan terlebih dahulu mengenai tahapantahapan dalam Model Lewin. Selanjutnya akan diuraikan bagaimana aktivitas dan proses dalam organisasi dilakukan dalam setiap tahapannya. Pada bagian ini juga akan diuraikan berbagai pendapat para ahli yang dapat meyakinkan bahwa teori klasik ini sesuai dalam menghadapi era disrupsi yang terjadi. Untuk menguatkan argument, beberapa contoh kasus perusahaan akan disertakan dalam penjelasannya.

\section{Hasil dan Pembahasan}

\subsection{Dinamika Disruptif Pada Lingkungan Bisnis Abad 21}

Memasuki dasawarsa pertama abad 21, lingkungan bisnis menghadapi perkembangan teknologi dan industrialisasi yang sangat pesat. Pada dasawarsa awal abad 21, dunia bisnis memasuki “ekonomi baru”. Drucker (1999) mengungkapkan karakteristik-karakteristik dalam kategori ekonomi baru tersebut. Pertama, ekonomi baru ditandai dengan pertumbuhan informasi yang begitu yang cepat, pengetahuan dan sumber daya usaha yang tidak berwujud seperti inovasi. Kedua, ekonomi baru didominasi oleh struktur ekonomi yang dikuasai jaringan yang logis sebagai hasil dari proses yang progresif berupa globalisasi, deregulasi, liberalisasi pasar dan model serta prilaku konsumen yang berubah (Fischer, 2003). 
Adanya globalisasi pasar dunia dipengaruhi oleh berbagai kebijakan liberalisasi perdagangan dan investasi di Asia Pasifik. Liberalisasi perdagangan merupakan penghapusan atau pengurangan hambatan (barriers) dalam perdagangan internasional. Hambatan ini baik berupa tarif ataupun non tariff. Tarif meliputi bea ekspor (duty) dan biaya tambahan, sedangkan non tarif meliputi aturan lisensi dan quota. Pengurangan hambatan-hambatan dalam perdagangan dapat mengakselerasi pertumbuhan, menyediakan stimulus akan bentuk spesialisasi produksi yang akan meningkatkan produktivitas serta dapat membuka lapangan kerja baik produsen domestic serta investor yang tentunya akan menciptakan kesempatan kerja yang pada akhirnya akan mengurangi kemiskinan di dunia (Rayan, 2002).

Pada masa ini semakin lingkungan bisnis juga ditandai oleh meluasnya jaringan organisasi dan komunikasi perusahaan global. Hal ini menciptakan membuka berbagai bentuk kerjasama internasional seperti joint ventures dan franchising. Joint ventures merupakan bentuk penanaman modal asing berupa penyelenggaraan bisnis yang dibentuk oleh dua atau lebih entitas bisnis dalam waktur tertentu. Penyelenggara bisnis ini terdiri dari dalam negeri dan luar negeri. Sedangkan franchising merupakan pemberian hak untuk memanfaatkan atau menjual baik produk atau jasa.

Pada dasawarsa kedua abad 21, muncul disrupsi atau gangguan yang merubah kondisi fundamental lingkungan bisnis secara mendunia. Pada saat ini dunia tengah menghadapi disrupsi teknologi, politik, ekonomi dan sosial budaya. Disrupsi teknologi ditandai dengan dunia memasuki masa Revolusi Industri 4.0 atan Industrial Revolution 4.0 (IR4.0) yang ditandai dengan adanya rekayasan intelegensia berupa internet of things, big data, artificial intelligence, human machine interface, robotic and sensor technology, 3d printing technology. Dengan demikian,IR 4.0 merupakan perpaduan teknologi yang menghilangkan batas antara fisik, digital dan bidang biologis. Dalam kondisi ini terjadi pertukaran informasi secara elektronik ke aplikasi strategi bisnis, pemasaran, penjualan hingga pelayanan pelanggan. Selain itu, internet berperan serta dalam mendukung komunikasi dan kerja sama global antara karyawan, konsumen, penjual dan rekanan bisnis lain.

Dari sisi ekonomi, disrupsi yang terjadi adalah munculnya kapitalisme secara ekstrim. Dalam kondisi ini pasar modal menyediakan inti, sumber utama dan kekuatan kapitalisme (Dobbs et al., 2014; El Namaki, 2015; Schwab, 2016). Dibidang sosial budaya, disrupsi meliputi tumbuhnya sosial media atau perangkat lunak berbasis teknologi yang memfasilitasi penciptaan dan berbagi segala bentuk ekspresi melalui jaringan dan komunitas virtual. Hal inilah yang menganggu peran kendaraan.

\subsection{Model Lewin Menghadapi Disrupsi Pada Lingkungan Bisnis Abad 21}

Kurt Lewin merupakan salah seorang pendiri dalam manajemen perubahan, melalui konsep unfreeze-movement-refreezing. Konsep ini kemudian dikenal sebagai paradigm klasik dalam mengelola perubahan (Robbins and Judge, 2003; Sonenshein, 2010; Waddell, 2007 ). Jeffcutt (1996) mendeskripsikan bahwa dalam perkembangan ilmu manajemen perubahan selanjutnya selalu mengikuti Model Lewin. 
Kurt Lewin memperkenalkan model perubahan terencana dalam 3 tahapan, yaitu Mencairkan (Unfreeze), pergerakan (Movement) dan Membekukan kembali (Refreeze). Menurut Lewin, langkah pertama dalam proses perubahan perilaku adalah mencairkan situasi atau status quo yang ada. Status quo disini dianggap sebagai keadaan keseimbangan yang berlaku. Proses mencairkan merupakan proses yang diperlukan untuk mengatasi tekanan secara individual dan kelompok serta dilakukan melalui 3 metode, pertama dengan meningkatkan faktor-faktor pengerak yang bisa menjauhkan individu atau kelompok dari situasi status quo yang berlaku saat ini.

\subsubsection{Proses Mencairkan (Unfreezing)}

Prilaku individu menurut lewin dapat menjadi penggerak ataupun penghambat perubahan (Lewin dalam Burnes, 2004). Dalam kondisi ini memungkinkan organisasi menghadapi karyawan yang sulit mengkonfirmasi sistem dalam tahap unfreezing tersebut sehingga menolak perubahan (Cummings \& Worley, 2005). Dengan demikian pada tahapan ini focus utama adalah bagaimana menjaga prilaku organisasi berada pada kondisi saat ini. Banyak organisasi mengalami kegagalan dalam melakukan perubahan pada tahap awal karena organisasi mengabaikan pentingnya prilaku dan kepercayaan karyawan yang menjadi sumber utama kesuksesan perubahan organisasi (Schein, 1999).

Tahap unfreezing dianggap sebagai tahapan yang paling penting dan kritis dalam lingkungan bisnis yang dinamis dan selalu berubah. Tahapan ini mengindikasikan kesiapan berubah yang meliputi pemahaman akan perubahan itu sendiri, pentingya perubahan dan mempersiapkan diri dan yang lainnya untuk keluar dari zona nyaman dan paradigm yang dianut sebelumnya sebelum perubahan nyata tersebut datang. Semakin sadarnya individu dalam organisasi merasakan perubahan merupakan hal yang penting, maka perubahan tersebut perlu dilakukan. Selanjutnya semakin mendesak perubahan tersebut harus dilakukan, individu yang ada di dalam organisasi akan semakin termotivasi untuk melakukan perubahan.

Kecenderungan individu yang resisten untuk menerima perubahan dan responsif hanya pada saat tenggat waktu, membuat perubahan tidak akan diterima jika sifatnya tidak urgent atau tidak ada motif yang kuat dan spesifik. Kajian yang dilakukan Elkjaer's (2001) mengidentifikasi bahwa karyawan yang kurang didukung oleh organisasinya cenderung memiliki pandangan dan kepercayaan yang negatif serta kurang komitmen terhadap organisasinya komitmen. Yang diperlukan pada tahap unfreezing adalah komunikasi yang terbuka antara organisasi dan karyawan. Dengan adanya komunikasi yang baik karyawan memiliki informasi yang cukup jelas mengenai perubahan yang terjadi termasuk didalamnya alasan-alasan logis yang melatarbelakangi perubahan tersebut serta manfaat yang akan diterima karyawan di masa yang akan datang.

Gambar 1. Force Fields Analysis

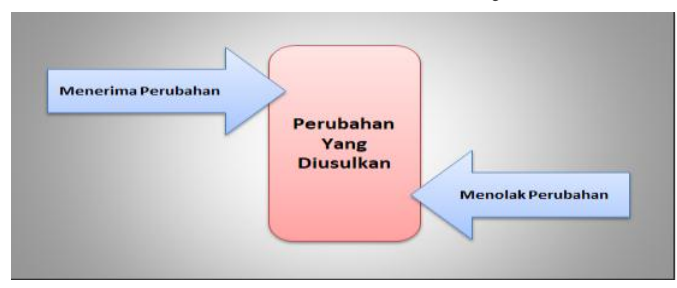


Tahapan unfreezing dalam model ini lebih mengarah kepada mengurangi hambatan-hambatan yang terjadi secara internal organisasi dan lebih memotivasi karyawan untuk ikut serta dalam perubahan organisasi. Kemudian secara spesifik proses ini lebih kepada menimbang dan mengidentifikasi pro dan kontra yang timbul sebelum memulai perubahan. Aktivitas ini dikategorikan Kurt Lewin sebagai analisa "Force Field", dimana analisa ini membantu untuk membobotkan berbagai faktor yang dapat mendorong dan menghambat dalam membuat perubahan (Cronshaw dan McCulloch, 2008). Analisis force fields sangat membantu organisasi dalam menghadapi perubahan sebagai akibat lingkungan bisnis sangat dinamis. Gagasan di balik Force Field Analysis adalah bahwa situasi dipertahankan oleh keseimbangan antara kekuatan yang mendorong perubahan dan yang lain yang menolak perubahan, seperti yang ditunjukkan pada gambar di bawah ini. Agar perubahan terjadi, kekuatan pendorong harus diperkuat atau kekuatan yang melawan melemah. Jika faktor pendukung atau pro kepada perubahan lebih besar dibandingkan yang menolak atau menghambat, maka perubahan akan di lakukan. Jika hasilnya adalah sebaliknya, maka terdapat motivasi yang rendah di kalangan individu dalam organisasi dan proses unfreezing tidak perlu dilakukan.

\subsubsection{Tahap Perubahan (Movement)}

Model Lewin lebih menekankan perubahan sebagai proses transisi dan bukan aktivitas. Tahap kedua pada model ini terjadi pada saat organisasi melakukkan perubahan atau transisi. Pola pikir individu-individu organisasi dalam tahap ini sudah berubah dari pola pikir yang lama dan sudah memiliki motivasi serta siap untuk perubahan yang berlaku. Dalam tahap ini penting bagi organisasi untuk dapat mengurangi rasa takut, kekhawatiran serta ketidakyakinan individu didalamnya akan perubahan yang akan dilakukan. Karena tidak mudah dan bukan waktu yang tepat bagi anggota organisasi untuk mempelajari dan memahami perubahan sehingga perlu diberikan waktu untuk mengerti, memahami dan berdiri bersama-sama anggota organisasi menghadapi perubahan.

Dalam tahap movement, intervensi organisasi sangat diperlukan. Campur tangan organisasi pada tahap ini meliputi struktur dan budaya organisasi. Wetzel dan Buch (2000) berpendapat bahwa intervensi organisasi harus sejalan dengan struktur perusahaan. Dukungan organisasi pada tahapan ini berbentuk pelatihan, mentoring dan mengidentifikasi bersama-sama bahwa kesalahan yang terjadi merupakan sebuah proses perubahan kearah yang lebih baik.

Salah satu contoh sukses perusahaan yang berhasil mengaplikasikan Model Lewin dalam transformasi organisasinya adalah British Airways (BA) (Goodstein dan Burke, 1991). Proses implementasi model Lewin pada BA mencapai 5 tahun, dari tahun 1982 sampai dengan tahun 1987 yang dilatarbelakangi perubahan status BA dari perusahaan milik swasta berganti menjadi perusahaan swasta. Pada tahapan movement, BA menyelenggarakan pelatihan untuk manajemen tingkat menengah dan atas (middle and senior manager). Pelatihan-pelatihan tersebut dibuat untuk meningkatkan pemahaman konsep pelayanan yang prima sebagai suatu perubahan BA dari organisasi yang berwawasan birokrasi menjdi organisasi yang berwawasan pelayanan konsumen. Selain pelatihan-pelatihan, pada tahapan in BA menyelenggarakan diskusi serta pertemuan-pertemuan untuk "sharing session" yang 
bertujuan untuk berbagi pengetahuan mengenai pembagian tugas, kinerja, pelayanan konsumen serta serta strategi BA kedepannya.

Adanya keteladanan, kepemimpinan, dan memungkinkan orang untuk mengembangkan solusi mereka sendiri akan membantu proses perubahan. Dengan kata lain tahapan ini memfokuskan pada kepemimpinan untuk memotivasi perubahan. Kajian yang dilakukan oleh Cummings dan Worley (2003) mempresentasikan lima aktivitas kunci dari kepemimpinan dalam proses perubahan, yaitu memotivasi perubahan, membuat visi, mengembangkan dukungan politik, mengelola setiap tahapan perubahan dan menjaga keberlangsungan perubahan serta membakukan perubahan yang sudah tetap.

Sedangkan kegiatan diskusi dan pertemuan-pertemuan "sharing session" merupakan ajang berbagi pengetahuan antar individu organisasi. Dalam tahapan movemen, kegiatan berbagi pengetahuan ini meliputi penugasan, pelayanan konsumen, kinerja hasil, aliran informasi antar level manajerial, membuat perencanaan bisnis, kondisi persaingan saat ini, peralatan teknologi baru, metode pekerjaan, ide-ide untuk perkembangan organisasi, berbagi keterampilan dan keahlian, pembagian program pengembangan dan ikut berkontribusi dalam pemecahan maalah serta kelangsungan operasi bisnis (Cummings dan Worley, 2003).

Dengan demikian, kegiatan berbagi pengetahuan dapat dikatakan sebagai hal yang penting dan krusial bagi setiap individu dalam organisasi (Wenger, McDermott, dan Snyder, 2002). Hakanson (1993) kemudian Foss dan Pedersen (2002), juga mengidentifikasi bahwa aktivitas ini penting bagi organisasi untuk menjaga stabilitas dan keberlangsungan orgnisasi itu sendiri. Sehingga dalam tahapan movement organisasi diharapkan tidak saja bergantung kepada pelatihan dan sistem pengelolaan saja namun juga pada kemampuan individu dalam membagikan pengetahuan, keterampilan, kompetensi serta kemampuan.

\subsubsection{Tahap Membekukan Kembali (Refreezing)}

Tahapan ini lebih kepada membangun stabilitas begitu perubahan telah sepenuhnya ditegakkan dan tertanam dalam individu-individu di organisasi. Disini perubahan telah diterima secara sepenuhnya dan menjadi norma serta status quo yang baru untuk dijadikan standar kerja. Individu-individu pada kondisi ini membentuk hubungan baru dan sudah merasa nyaman dengan rutinitas baru mereka. Model Lewin pada tahap ini mengindikasikan bahwa organisasi harus distabilisasi dan dilembagakan dalam bentuk yang baru setelah tahap pergerakan atau "movement". Status quo yang baru dalam kondisi ini harus diperkuat secara institusional serta proses institusionalisasi perubahan inilah yang merupakan langkah akhir yang menentukan keberhasilan keberlanjutan perubahan (Kotter, 1995).

Poin utama dari tahapan refreezing ini adalah pada kondisi tertentu, perilaku harus kongruen dengan keseluruhan lingkungan, perilaku, dan personal dari individu, karena jika tidak perubahan yang terjadi tidak dapat dikonfirmasi (Schein, 1996). Dalam melakukan institusionalisasi perubahan-perubahan yang telah tetap tersebut, membutuhkan pemimpin yang menerbitkan berbagai program-program perubahan sehingga perubahan tersebut menjadi suatu kebiasaan yang harus dilakukan (Kotter, 2007). 
Diperlukan upaya yang cukup besar dalam memastikan perubahan tersebut diaplikasikan, tidak hilang serta dijaga keberlangsungannya. Salah satu usaha yang perlu dilakukan adalah dengan memperkuat dan menanam perubahan dalam buadaya organisasi dan diaplikasikan dalam cara berfikir dan bertindak baik bagi individu atau organisasi. Untuk menjga keberlangsungan, penghargaan yang positif serta pengakuan dilakukan untuk memperkuat status quo yang baru karena dipercaya bahwa memperkuat prilaku akan terus diulangi.

Dalam hal ini peran pimpinan organisasi diperlukan untuk membuat koneksi antara program yang sebelumnya diujicobakan yang dikategorikan sebagai "single loop" dan menginterkoneksi perubahan sistem-sistem yang ada untuk menjadi "double loop". Contohnya adalah perubahan pada tingkat bawah organisasi akan berdampak pada perbaikan sistem-sistem yang ada. Pada intinya, tahapan ini memerlukan pimpinan yang memiliki kemampuan dalam memahami bagaimana sistem bekerja dan harus merubah tradisi mental yang selama ini pada organisasi (Senge, 2006).

\section{Simpulan}

Teori Lewin yang dipandang sebagai teori yang sangat klasik dalam manajemen perubahan organisasi dapat diandalkan sebagai keberhasilan organisasi masa kini dalam proses perubahannya sebagai usaha untuk beradaptasi dengan berbagai disrupsi dalam lingkungan bisnis saat ini. Melalui tiga tahapan Lewin berupa Unfreezing-Movement-Refreezing, Model Lewin mengedepankan individu atau manusia sebagai akar dari perubahan. Selain itu, Model Lewin menitikberatkan pada identifikasi faktor pendorong dan penghambat dalam resistensi manajemen perubahan organisasi. Faktor pendorong merupakan alasan individu dalam organisasi termotivasi untuk ikut melakukan perubahan. Di sisi lain faktor penghambat merepresentasikan alasan individu dalam organisasi enggan untuk melakukan perubahan. Sehingga dapat disimpulkan bahwa apapun disrupsi yang terjadi pada lingkungan bisnis, jika organisasi mampu mendorong dan memotivasi individu didalamnya untuk ikut serta dalam perubahan, maka perubahan organisasi akan berhasil dilakukan.

Selain itu, adanya disrupsi akan membawa perubahan yang lebih baik lagi pada organisasi jika gaya kepemimpinan lebih berorientasi pada keterlibatan, komitmen dan dukungan yang tinggi akan proses perubahan. Hal ini peran kepemimpinan yang dominan serta keterlibatan karyawan dalam proses perubahan sangat diperlukan untuk efektivitas perubahan dalam manajemen. Di sisi lain, Model Lewin mengidentifikasi adanya hubungan yang signifikan dalam berbagi pengetahuan dalam proses perubahan antara pimpinan dengan individu organisasi atau karyawan menjadi akar yang kuat dalam keberhasilan organisasi menjalani perubahan sebagai akibat dari adanya disrupsi.

\section{Daftar Pustaka}

Bower, J. L., \& Christensen, C. M. (1995). Disruptive technologies: Catching the wave. Harvard Business Review. [online] Available : https://hbr.org/1995/01/disruptivetechnologies-catching-the-wave (July 27, 2020)

Calder, A. M. (2013). Organizational change: Models for successfully implementing change. Undergraduate Honors Capstone Projects. 144. [online] Available : https://digitalcommons.usu.edu/honors/144 (June 10, 2020)

Camp, W. (2001). Formulating and evaluating theoretical frameworks for career and technical education research. Journal of Vocational Education Research, 26(1), 4-25. 
Clarke, S. (1999). Perceptions of organizational safety: implications for the development of safety culture. Journal of Organizational Behavior: The International Journal of Industrial, Occupational and Organizational Psychology and Behavior, 20(2), 185-198.

Cronshaw, S. F., \& McCulloch, A. N. (2008). Reinstating the Lewinian vision: From force field analysis to organization field assessment. Organization Development Journal, 26(4), 89.

Cummings, T. G., \& Worley, C. G. (2003). Organization Development and Change (1-694). California, Melissa S. Acuna.

Cummings, T. G. (2005). en CG Worley (2005). Organization development and change. Mason, Ohio : Thomson/South-Western.

Elkjaer, B. (2001). The learning organization: an undelivered promise. Management learning, $32(4), 437-452$.

Drucker, P. F. (1999). Knowledge-worker productivity: The biggest challenge. California management review, 41(2), 79-94.

El Namaki, M. S. S. (2015). Strategies for offense and defense in global capital markets. Scholedge International Journal of Management \& Development, 2(5), 68-74.

Goodstein, L. D., \& Burke, W. W. (1991). Creating successful organization change. Organizational Dynamics, 19(4), 5-17.

Håkanson, L., \& Nobel, R. (1993). Foreign research and development in Swedish multinationals. Research Policy, 22(5-6), 373-396.

Jeffcutt, P. (1996). The organization of performance and the performance of organization. Studies in Cultures, Organizations and Societies, 2(1), 95-110.Lewin dalam Burnes, 2004)

Kotter, J. P. (1995). Leading Change: Why transformation efforts fail. Harvard Business Review. [online] Available : https://hbr.org/1995/05/leading-change-why-transformationefforts-fail-2 (June 10, 2020)

Mellita, D., Aliya, S., \& Elfanso, E. (2020). Green Supply Chain Management at Cullinary Small Business: Some Notes To Consider. Dinasti International Journal of Digital Business Management, Volume 1, No. 4, 512-521.

Rayan, D. (Ed.). (2002). Empowerment and poverty reduction: A sourcebook. The World Bank.

Robbins, S. B., Davenport, M., Anderson, J., Kliewer, W., Ingram, K., \& Smith, N. (2003). The role of motivation and self-regulatory behaviors on first-year college adjustment. Unpublished manuscript. Iowa City, IA: ACT.

Robbins, S. P. (2005). Principles of organizational behavior. Translated by Parsaeian A, Arabi M. Ninth printing. Publications Cultural Research Bureau in Tehran.

Roussel, L., Swansburg, R. C., \& Swansburg, R. J. (Eds.). (2006). Management and leadership for nurse administrators. Jones \& Bartlett Learning.

Schwab, K. (Ed.). (2016). The global competitiveness report 2016-2017: insight report. World Economic Forum.

Senge, P. M. (2006). The fifth discipline: The art and practice of the learning organization. Currency. 
Sonenshein, S. (2010). We're changing-Or are we? Untangling the role of progressive, regressive, and stability narratives during strategic change implementation. Academy of Management Journal, 53(3), 477-512.

Waddell, D., Cummings, T. G., \& Worley, C. G. (2007). Organisation, development and change-Asia Pacific. Thomson.

Wenger, E., McDermott, R. A., \& Snyder, W. (2002). Cultivating communities of practice: A guide to managing knowledge. Harvard Business Press.

Wetzel, D. K., \& Buch, K. (2000). Using a structural model to diagnose organizations and develop congruent interventions. Organization Development Journal, 18(4), 9.

Wren, J., \& Dulewicz, V. (2005). Leader competencies, activities and successful change in the Royal Air Force. Journal of change management, 5(3), 295-309.

\section{Copyright Disclaimer}

Copyright for this article is retained by the author(s), with first publication rights granted to the journal. 